\title{
EFFECT OF PROTAMINE ON PLASMA IONIZED CALCIUM IN THE DOG
}

\author{
Ronald M. Jones, Anne B. Hill, Michael L. Nahrwold and Alan R. Tait
}

\begin{abstract}
Ten anaesthetized, heparinized healthy adult dogs were infused with protamine sulphate $3 \mathrm{mg} \cdot \mathrm{kg}^{-1}$ and plasma ionized calcium was measured. A significant $(p<0.01)$ decrease in ionized calcium occurred which preceded the maximal reduction in cardiac output and systemic arterial pressure. The elinical implications of these results are discussed.
\end{abstract}

KEY WoRDs: BLOOD, plasma ionized calcium; Protamine.

SYSTEMIC ARTERIAL HYPOTENSION MAY Occur during the infusion of protamine sulphate, which is used to reverse the action of heparin at the termination of cardiopulmonary bypass. It is the clinical impression of many anaesthetists that the administration of calcium in the form of calcium chloride may reverse the circulatory effects of protamine. Protamine is a large negatively charged molecule which may be capable of binding ionized calcium $\left(\mathrm{Ca}^{++}\right)$, a reduction in which is known to cause a decrease in cardiac output and hypotension. We therefore measured $\mathrm{Ca}^{++}$as well as potassium $\left(\mathrm{K}^{+}\right)$and sodium $\left(\mathrm{Na}^{+}\right)$, during and following the infusion of protamine sulphate.

\section{Methods}

Ten healthy dogs weighing 26 to $33 \mathrm{~kg}$ were anaesthetized with pentobarbitone $30 \mathrm{mg} \cdot \mathrm{kg}^{-1}$ intravenously, paralyzed with pancuronium 0.1 $\mathrm{mg} \cdot \mathrm{kg}^{-1}$ and ventilated with 0.5 per cent enflurane in 70 per cent nitrous oxide with oxygen. The left femoral vein and both femoral arteries were cannulated and a thermal dilution Swan-Ganz catheter was inserted in the pulmonary artery through the right external jugular vein. Electrocardiogram, heart rate and systolic and diastolic systemic arterial pressures were recorded continuously using a Gould six channel recorder.

Ronald M. Jones, M.B., Ch.B., F.F.A.R.C.S., Instructor ; Anne B. Hill, M.B., Ch.B., F.F.A.R.C.S., Associate Professor; Michael L. Nahrwold, M.D., Professor; Alan R. Tait, B.Sc., Research Asociate; Department of Anesthesiology, The University of Michigan Medical Center, Ann Arbor, Michigan 48109 U.S.A.

Address correspondence to Dr. Jones at The City Hospital, Department of Anaesthesia, Hucknall Road, Nottingham, United Kingdom.
The dogs were ventilated to keep the $\mathrm{PaCO}_{2}$ between 5.2 and $5.4 \mathrm{kPa}$ and normal saline was infused to maintain the haematocrit between 38 and 42 per cent. After a steady state had been achieved, heparin ( $3 \mathrm{mg} \cdot \mathrm{kg}^{-1}$ ) was given as a bolus. After 30 minutes, protamine sulphate $3 \mathrm{mg} \cdot \mathrm{kg}^{-1}$ was given over 3 minutes through the left femoral vein, using a Sage syringe pump. Cardiac output (thermal dilution) and arterial blood gases were measured before the introduction of 0.5 per cent enflurane (control) 10 minutes after 0.5 per cent enfurane, $1,5,15$, and 25 minutes after heparinization and $1,2,3$, $4,5,10,15$, and 30 minutes after the start of the infusion of protamine.

$\mathrm{Ca}^{++}, \mathrm{K}^{+}$, and $\mathrm{Na}^{+}$were measured using ion-specific electrodes (Orion models SS-20 and SS-30, respectively), samples being analyzed in a random manner. Each sample was analyzed twice, the mean of the two results being used. The electrodes were recalibrated after every four analyses. The largest difference recorded for estimations on the sample site were $\mathrm{Na}^{+} 1.5$ $\mathrm{mmol} / \mathrm{l}, \mathrm{K}^{+} 0.06 \mathrm{mmol} / \mathrm{l}$, and $\mathrm{Ca}^{++} 0.015$ $\mathrm{mmol} / \mathrm{l}$. The data were subjected to paired t-tests, $\mathrm{p}<0.05$ considered significant.

\section{RESULTS}

Cardiac output, $\mathrm{Ca}^{++}, \mathrm{Na}^{+}$, and $\mathrm{K}^{+}$were not significantly altered after 0.5 per cent enflurane or by heparinization (Table I).

There was a dramatic reduction in cardiac output and systemic arterial pressure within two minutes of the start of the protamine infusion, maximal after 3 minutes (Table II). This was associated with arterial hypoxia. The mean $\mathrm{Ca}^{++}$was significantly reduced one minute after the start of the protamine infusion, the 65

Can. Anaesth. Soc. J., vol. 29, no. 1, January 1982 
TABLE I

Effect of 0.5 Per Cent Enflurane and Heparinization (MEANS \pm SD)

\begin{tabular}{lcccc}
\hline & $\begin{array}{c}\mathrm{Q} \\
\text { Litres/Min }\end{array}$ & $\begin{array}{c}\mathrm{Ca}^{++} \\
\mathrm{mmol} / \text { litre }\end{array}$ & $\begin{array}{c}\mathrm{Na}^{+} \\
\mathrm{mmol} / \text { litre }\end{array}$ & $\begin{array}{c}\mathrm{K}^{+} \\
\mathrm{mmol} / \text { litre }\end{array}$ \\
\hline Control & $3.6 \pm 1.0$ & $1.27 \pm 0.09$ & $147.8 \pm 3.1$ & $4.06 \pm 0.42$ \\
$\mathrm{E}_{10}$ & $3.5 \pm 1.2$ & $1.26 \pm 0.13$ & $147.8 \pm 3.0$ & $4.02 \pm 0.39$ \\
$\mathrm{H}_{1}$ & $3.6 \pm 1.3$ & $1.24 \pm 0.12$ & $148.2 \pm 3.8$ & $4.07 \pm 0.40$ \\
$\mathrm{H}_{5}$ & $3.5 \pm 1.2$ & $1.26 \pm 0.13$ & $148.2 \pm 3.4$ & $4.06 \pm 0.36$ \\
$\mathrm{H}_{15}$ & $3.5 \pm 1.3$ & $1.27 \pm 0.09$ & $148.0 \pm 3.0$ & $4.07 \pm 0.31$ \\
$\mathrm{H}_{25}$ & $3.5 \pm 1.4$ & $1.26 \pm 0.13$ & $146.7 \pm 3.4$ & $4.09 \pm 0.39$ \\
\hline
\end{tabular}

There was no significant change in any variable $(p>0.05)$ after 10 minutes of 0.5 per cent Enflurane $\left[E_{10}\right]$ or $1,5,15$, and 25 minutes after heparinization ( $\left.3 \mathrm{mg} \cdot \mathrm{kg}^{-1}\right)\left[\mathrm{H}_{1}, \mathrm{H}_{5}, \mathrm{H}_{15}, \mathrm{H}_{25}\right]$.

$Q=$ cardiac output.

TABLE II

Effect of Infusion of Protamine $3 \mathrm{mg} \cdot \mathrm{kg}^{-1}$ Over Three Minutes (Means \pm SD)

\begin{tabular}{|c|c|c|c|c|c|c|c|c|}
\hline & $\stackrel{\mathrm{Q}}{\text { Litres/Min }}$ & $\underset{\mathrm{mmHg}}{\mathrm{SAP}}$ & $\mathrm{pH}$ & $\begin{array}{l}\mathrm{PO}_{2} \\
\mathrm{kPa}\end{array}$ & $\begin{array}{c}\mathrm{PCO}_{2} \\
\mathrm{kPa}\end{array}$ & $\begin{array}{c}\mathrm{Ca}^{++} \\
\mathrm{mmol} / 1\end{array}$ & $\underset{\mathrm{mmol} / \mathrm{l}}{\mathrm{Na}^{+}}$ & $\underset{\mathrm{mmol} / \mathbf{l}}{\mathrm{K}^{+}}$ \\
\hline Control & $\begin{array}{r}3.6 \\
\pm 1.0\end{array}$ & $\begin{array}{r}154 \\
\pm 21\end{array}$ & $\begin{array}{r}7.33 \\
\pm 0.03\end{array}$ & $\begin{aligned} & 17.8 \\
+ & 49\end{aligned}$ & $\begin{array}{r}5.3 \\
\pm 0.3\end{array}$ & $\begin{array}{r}1.27 \\
\pm 0.09\end{array}$ & $\begin{array}{l}147.8 \\
\pm 3.1\end{array}$ & $\begin{array}{r}4.06 \\
\pm 0.42\end{array}$ \\
\hline 1 & $\begin{array}{r}3.5 \\
\pm 1.4\end{array}$ & $\begin{array}{l}136 t \\
\pm 23\end{array}$ & $\begin{array}{r}7.33 \\
\pm 0.04\end{array}$ & & & & & \\
\hline 2 & $\begin{array}{r}1.81 \\
+0.9\end{array}$ & $\begin{array}{r}70^{l l} \\
+14\end{array}$ & $\begin{array}{r}7.33 \\
+\quad 0.05\end{array}$ & $\begin{array}{r}18.2 \\
+5.6\end{array}$ & $\begin{array}{r}-0.4 \\
5.4 \\
+0.5\end{array}$ & $\begin{array}{c}-0.14 \\
1.149 \\
+011\end{array}$ & 144.11 & $\begin{array}{r}3.91 \\
+0.47\end{array}$ \\
\hline 3 & $\begin{array}{r}1.5^{\| 1} \\
\pm 0.7\end{array}$ & $\begin{array}{r}60^{4} \\
\pm 12\end{array}$ & $\begin{array}{r}7.33 \\
\pm 0.05\end{array}$ & $\begin{array}{l}15.4 \ddagger \\
\pm 5.9\end{array}$ & $\begin{array}{r}5.3 \\
\pm 0.5\end{array}$ & $\begin{array}{l}1.18 \S \\
\pm 0.13\end{array}$ & $\begin{array}{l}144.1^{\| 1} \\
\pm 4.2\end{array}$ & $\begin{array}{r}4.18 \\
\pm 0.51\end{array}$ \\
\hline 4 & $\begin{array}{l}1.6 \| \\
\pm 0.6\end{array}$ & $\begin{array}{r}6511 \\
\pm 18\end{array}$ & $\begin{array}{r}7.31 \\
\pm 0.04\end{array}$ & $\begin{array}{r}12.59 \\
\pm 5.9\end{array}$ & $\begin{array}{r}5.4 \\
\pm 0.7\end{array}$ & $\begin{aligned} & 1.22 \dagger \\
\pm & 0.08\end{aligned}$ & $\begin{array}{l}144.69 \\
\pm 4.0\end{array}$ & $\begin{array}{r}4.18 \\
+0.44\end{array}$ \\
\hline 5 & $\begin{aligned} & 1.9 \| \\
\pm & 0.8\end{aligned}$ & $\begin{array}{r}80^{11} \\
\pm 28\end{array}$ & $\begin{array}{l}7.29 * \\
\pm 0.03\end{array}$ & $\begin{array}{l}11.39 \\
\pm 5.8\end{array}$ & $\begin{array}{r}5.7 \\
\pm 0.7\end{array}$ & $\begin{array}{r}1.24 \\
\pm 0.09\end{array}$ & $\begin{array}{l}145.4 \dagger \\
\pm 3.9\end{array}$ & $\begin{array}{r}4.25 \\
\pm 0.44\end{array}$ \\
\hline 10 & $\begin{aligned} & 2.5^{\prime \prime} \\
\pm & 0.8\end{aligned}$ & $\begin{array}{c}10711 \\
\pm 25\end{array}$ & $\begin{aligned} & 7.2511 \\
\pm & 0.04\end{aligned}$ & $\begin{array}{l}11.89 \\
\pm 5.8\end{array}$ & $\begin{array}{r}6.47 \\
\pm 1.1\end{array}$ & $\begin{array}{r}1.24 \\
\pm 0.09\end{array}$ & $\begin{array}{l}145.7 \ddagger \\
\pm 3.3\end{array}$ & $\begin{array}{r}4.28 \\
\pm 0.41\end{array}$ \\
\hline 15 & $\begin{array}{r}2.8 \| \\
\pm 0.9\end{array}$ & $\begin{array}{l}1161 \\
\pm 20\end{array}$ & $\begin{aligned} & 7.27^{*} \\
\pm & 0.05\end{aligned}$ & $\begin{array}{l}14.2 \ddagger \\
\pm 5.7\end{array}$ & $\begin{aligned} & 6.19 \\
\pm & 0.7\end{aligned}$ & $\begin{array}{r}1.25 \\
\pm 0.11\end{array}$ & $\begin{array}{r}146.7 \\
\pm 2.6\end{array}$ & $\begin{array}{r}4.07 \\
+0.37\end{array}$ \\
\hline 30 & $\begin{aligned} & 3.1^{11} \\
\pm & 1.1\end{aligned}$ & $\begin{array}{l}1259 \\
\pm 20\end{array}$ & $\begin{aligned} & 7.29 \dagger \\
+ & 0.05\end{aligned}$ & $\begin{array}{r}16.0 \\
\pm 5.9\end{array}$ & $\begin{array}{r}5.7 \\
\pm 0.5\end{array}$ & $\begin{array}{r}1.22 \\
+0.10\end{array}$ & $\begin{array}{r}146.9 \\
\pm 3.5\end{array}$ & $\begin{array}{r}3.95 \\
+0.39\end{array}$ \\
\hline
\end{tabular}

maximal reduction occurring two minutes after the start of the infusion. This reduction was greater than could be accounted for by dilution. The small reduction in $\mathrm{Na}^{+}$however, probably represents dilution caused by the volume of the protamine infusion.

\section{Discussion}

The use of protamine to reverse the action of heparin was first suggested by Chargaff and Olson in $1937,{ }^{1}$ but the deleterious effects of protamine on the circulation were first described by Thomson in $1900 .^{2}$

The hypotension that may occur during protamine infusion is due to effects on the myocardium and peripheral circulation, and is not mediated through autonomic blockade, postganglionic parasympathetic receptors, alpha or beta receptors, or histamine release. ${ }^{3}$ The relative contribution to the circulatory depression of the effects on the myocardium and the peripheral vasculature has been open to much discussion. Jaques, studying the species difference in re- 
sponse to protamine administration, found the dog to be the most vulnerable and concluded that arteriolar dilatation was responsible for the hypotension. ${ }^{2}$ Gourin, Streisand and Stuckey, ${ }^{4}$ using an isovolumic left canine ventricle preparation, later concluded that the reduction in cardiac output was secondary to a reduction in venous retum to the heart (pre-load) and indeed reported a transient positive inotropic effect on the myocardium. Susbsequent reports by Iwatsuki, Matsukawa, and Iwatsuki ${ }^{5}$ using an isolated canine heart muscle preparation and Marin-Neto, Sykes, Marin, Orchard and Chakrabarti ${ }^{6}$ under controlled conditions of heart rate and proximal aortic pressure in heparinized dogs, have shown that a reduction in myocardial contractility plays at least some part in the circulatory depression caused by protamine. A reduction in plasma $\mathrm{Ca}^{++}$is known to cause a decrease in myocardial contractility ${ }^{7}$ and it is the clinical impression of many anaesthetists that the administration of $\mathrm{Ca}^{++}$in the form of $\mathrm{CaCl}_{2}$ will readily reverse the circulatory effects of protamine. Our results indicate that the slow infusion of protamine $\left(3 \mathrm{mg} \cdot \mathrm{kg}^{-1}\right)$ does significantly reduce the $\mathrm{Ca}^{++}$ in anaesthetized heparinized dogs. The 10 per cent reduction in $\mathrm{Ca}^{++}$which occurred in our experiment was unlikely to have been the sole cause of the circulatory depression. The significance of a 10 per cent reduction in $\mathrm{Ca}^{++}$will vary according to circumstances. Many patients do not suffer haemodynamic disturbances during protamine infusion and, in these patients, a 10 per cent reduction in $\mathrm{Ca}^{++}$presumably has little significance. However Westhorpe, Varghese, Petrie, Wills and Lumley ${ }^{8}$ have shown that a combination of haemodilution and citrate binding by stored blood used to prime the pump may lead to a lowering of the $\mathrm{Ca}^{++}$in the postbypass period. Thus, at termination of cardio- pulmonary bypass, the $\mathrm{Ca}^{++}$level may already be low and further reduction by binding to protamine may reduce this to a level which may cause significant myocardial depression. We conclude that protamine causes a reduction in plasma $\mathrm{Ca}^{++}$in the dog and that if binding of $\mathrm{Ca}^{++}$also occurs in man this may be of clinical significance in certain circumstances, for example during the post-bypass period of cardiac surgery.

\section{REFERENCES}

1. Chargaff, E. \& Olson, K. Studies on the chemistry of blood coagulation. J. Biol. Chem. 122: 153 (1937)

2. JAQUES, L.B. A study of the toxicity of the protamine, salmine. Br. J. Pharmacol. 4: 135 (1949).

3. Fadali, M.A., Papacostas, C.A., Duke, J.J., LedbetTER, M. \& OSBAKKen, M. Cardiovascular depressant effect of protamine sulphate: experimental study and clinical implications. Thorax 31: 320 (1976).

4. Gourin, A., Streisand, R.L. \& Stuckey, J.H Total cardiopulmonary bypass, myocardial contractility, and the administration of protamine sulfate. J. Thorac. Cardiovasc. Surg. 61: 160 (1971).

5. Imatsuki, N., Matsukawa, S. \& Iwatsuki, K. A weak negative inotropic effect of protamine sulfate upon the isolated canine heart muscle. Anesth. Analg. 59: 100 (1980).

6. Marin-Neto, J.A., Sykes, M.K., Marin, J.L.B., OrChard, C. \& Chakrabarti, M.K. Effects of heparin and protamine on left ventricular performance in the dog. Cardiovasc. Res. 13: 254 (1979)

7. BUNXER, J.P. Metabolic effects of blood transfusion. Anesthesiology 27: 446 (1966).

8. Westhorpe, R.N., Varghese, Z., Petrie, A. WILLS, M.R. \& Lumley, J. Changes in ionized calcium and other plasma constituents associated with cardiopulmonary bypass. Br. J. Anaesth. 50: 951 (1978).

\section{RÉsumé}

On a mesuré le calcium plasmatique ionisé après l'administration de sulfate de protamine à la dose de $3 \mathrm{mg} \cdot \mathrm{kg}^{-1}$ chez dix chiens normaux, héparinisés, sous anesthésie générale. On a observé une diminution significative $(p<0.01)$ du calcium ionisé. Cette diminution précédait la diminution maximale du débit cardiaque et de la pression artérielle que l'on a observée. Les implications cliniques de ces résultats sont discutées. 